\title{
UPAYA MENINGKATKAN MOTIVASI BELAJAR, AKTIVITAS BELAJAR DAN PRESTASI BELAJARMELALUI STRATEGI DIRECT INSTRUCTION
}

\author{
Nur Salim ${ }^{1}$ Moh Nasuka ${ }^{2}$ M. Novailul Abid ${ }^{3}$ \\ ${ }^{1}$ Institut Agama Islam Negeri Syekhnurjari Cirebon \\ ${ }^{2}$ Universitas Islam Nahdlatul Ulama Jepara \\ ${ }^{3}$ Universitas Islam Nahdlatul Ulama Jepara \\ Email : nursalim@gmail.com ${ }^{1}$, mohnasuka@unisnu.ac.id ${ }^{2}$ noval@unisnu.ac.id ${ }^{3}$
}

DOI: https://doi.org/10.37758/jat.v3i1.202

\begin{tabular}{l|l|l} 
Received: Maret 2020 & Accepted: Juni 2020 & Published: Juni 2020
\end{tabular}

\begin{abstract}
:
This study describes the application of the direct instruction learning model in improving learning motivation, learning activities and student achievement in the moral subjects of the eighth grade MTs YAPIN Kertasemaya Indramayu. The type of research used is Classroom Action Research (CAR) or Classroom Action Research (CAR). The subjects of this study were the eighth grade students of MTs YAPIN Kertasemaya Indramayu, totaling 30 students. The instrument used to obtain preliminary data was the daily scores of students, data on student achievement was carried out objective tests carried out at the end of each cycle, and questionnaires to obtain data on learning motivation and observation to obtain data on student learning activities.

The results of this study indicate there is a significant increase in each cycle. To increase student motivation, the average cycle I was $49.6 \%$, the second cycle was $77.8 \%$ and the average cycle III was $81.3 \%$. To increase learning activities in the first cycle by $68.9 \%$, while the average cycle II was $77.75 \%$ and the average cycle III was $86.6 \%$. As for the increase in learning outcomes that can be seen from the results of the classical learning completeness percentage in the first cycle by $40 \%$, in the second cycle by $60 \%$ and in the third cycle by $80 \%$.
\end{abstract}

Key words : Direct Instruction, Learning Motivation, Learning Activities, Learning Achievement.

Abstrak:

Penelitian ini mendeskripsikan penerapan model pembelajaran direct instruction dalam meningkatkan motivasi belajar, aktivitas belajar dan prestasi belajar siswa pada mata pelajaran Akidah Akhlak kelas VIII MTs YAPIN Kertasemaya Indramayu.Jenis penelitian yang digunakan adalah Penelitian Tindakan Kelas (PTK) atau Classroom Action Research (CAR). Subyek penelitian ini adalah siswa kelas VIII MTs YAPIN Kertasemaya Indramayu yang berjumlah 30 siswa. Instrumen yang digunakan untuk memperoleh data awal adalah nilai harian siswa, data prestasi belajar siswa dilakukan tes objektif yang dilaksanakan disetiap akhir siklus, dan angket untuk memperoleh data motivasi belajar serta observasi untuk memperoleh data aktivitas belajar siswa.

Hasil penelitian ini menunjukan terdapat peningkatan secara signifikan pada setiap siklusnya. Untuk peningkatan motivasi belajar siswa rata-rata siklus I sebesar $49,6 \%$, pada siklus II sebesar $77,8 \%$ dan rata-rata siklus III sebesar 81,3\%. Untuk peningkatan aktivitas belajar pada siklus I sebesar $68,9 \%$, sedangkan rata-rata siklus II sebesar $77,75 \%$ dan rata-rata siklus III sebesar 86,6\%. Sedangkan untuk peningkatan hasil belajar yang dapat dilihat dari hasil prosentase ketuntasan belajar secara klasikal yaitu pada siklus I sebesar $40 \%$, pada siklus II sebesar $60 \%$ dan pada siklus III sebesar $80 \%$.

Kata Kunci : Direct Instruction, Motivasi Belajar, Aktivitas Belajar, Prestasi Belajar 


\section{PENDAHULUAN}

Metode mengajar dalam dunia pendidikan perlu dimiliki oleh pendidik, karena keberhasilan kegiatan belajar mengajar tergantung pada model yang digunakan oleh gurunya. Jika model mengajar guru menyenangkan dan mudah dipahami, maka siswa akan tekun, rajin, dan antusias menerima pelajaran yang diberikan. Pada gilirannya diharapkan akan terjadi perubahan tingkah laku pada siswa baik tutur katanya, sopan santunnya, monotoriknya dan gaya hidupnya.

Beberapa kendala dalam pembelajaran Akidah Akhlak di MTs Yapin Kertasemaya Indramayu antara lain, pertama, materi Akidah Akhlak adalah ilmu praktis tentang kaidah atau aturan main yang berfungsi menata kehidupan manusia baik dalam hubungan manusia dengan Allah SWT, dengan diri manusia itu sendiri, sesama manusia, maupun hubungan dengan lingkungannya. Seperti kami dapat contohkan dalam Wibowo (2018) menjelaskan perbedaan antara siswa yang belajar dilingkungan tertentu sangat mempengaruhi mindset dan hasil belajar1. Kedua, kebosanan siswa dan proses pembelajaran yang monoton di kelas perlu solusi alternatif sebagai upaya untuk meningkatkan pengetahuan kognitif, afektif, dan psikomotorik.

Dari pengamatan dan wawancara terhadap pihak sekolah serta guru mata pelajaran Akidah Akhlak terhadap proses pelaksanaan belajar mengajar dan prestasi belajar Akidah Akhlak di MTs Yapin Kertasemaya Indramayu, ditemukan beberapa permasalahan, diantaranya: 1) Model pembelajarannya masih satu arah (ceramah) belum bervariasi sehingga pelajaran yang seharusnya dikuasai dengan baik oleh siswa hasilnya kurang optimal hal ini dapat diketahui dari nilai ulangan harian hanya 39\% dari jumlah KKM yang ditetapkan. 2) aktivitas belajar siswa juga masih rendah yaitu 32\% siswa yang aktif dan $68 \%$ orang siswa pasif. Hal ini disebabkan karena siswa tidak merasa dilibatkan dalam kegiatan belajar mengajar. 3) Motivasi belajar siswa juga relatif masih rendah, hal ini disebabkan kurangnya minat belajar untuk semangat belajar, dan kurangnya motivasi dari orang tua. 4) Prestasi belajar siswa juga masih rendah,

\footnotetext{
${ }^{1}$ Adi Wibowo, "STUDY KOMPARASI PENYELENGGARAAN PENDIDIKAN SMK(Studi Kasus SMK Di Pondok Pesantren Lirboyo Al-Mahrusiyah Dan Di SMK PGRI 2 Kediri)," At-Tarbiyat :Jurnal Pendidikan Islam 1, no. 2 (2018): 1-22, doi:10.37758/jat.v1i1.100.
}

68 | At-Tarbiyat : Jurnal Pendidikan Islam, Vol. 03 No. 01 (2020) : 67-85 
terutama jika dibandingkan dengan mata pelajaran Pendidikan Agama Islam (PAI) lainnya. Berdasarkan atas latar belakang tersebut, tulisan ini akan membahas tentang bagaimana penerapan strategi direct instruction dan adakah peningkatan motivasi dan belajar siswa di MTs Yapin Kertasemaya Indramayu.

\section{Metode}

Penelitianini merupakan Penelitian Tindakan Kelas (PTK) atau Classroom Action Research (CAR). Metode yang digunakan dalam tulisan ini deskriptifkualitatif dengan sumber data lapangan sebagai sumber primernya dan buku, artikel, serta informasi lain yang tersebar di internet sebagai data sekundernya. Teknik penggalian datanya menggunakan teknik wawancara, observasi dan dokumentasi. Data yang tersedia dianalisis dengan menggunakan acuan Kemmis dan Taggart terdiri dari empat rangkaian kegiatan yang dilakukan dalam siklus berulang yang merupakan ciri penelitian tindakan. Keempat rangkaian kegiatan yang dilakukan dalam setiap siklus tersebut berupa: rencana tindakan (action plan), tindakan (action), pengamatan (observation), refleksi (reflection) ${ }^{2}$.

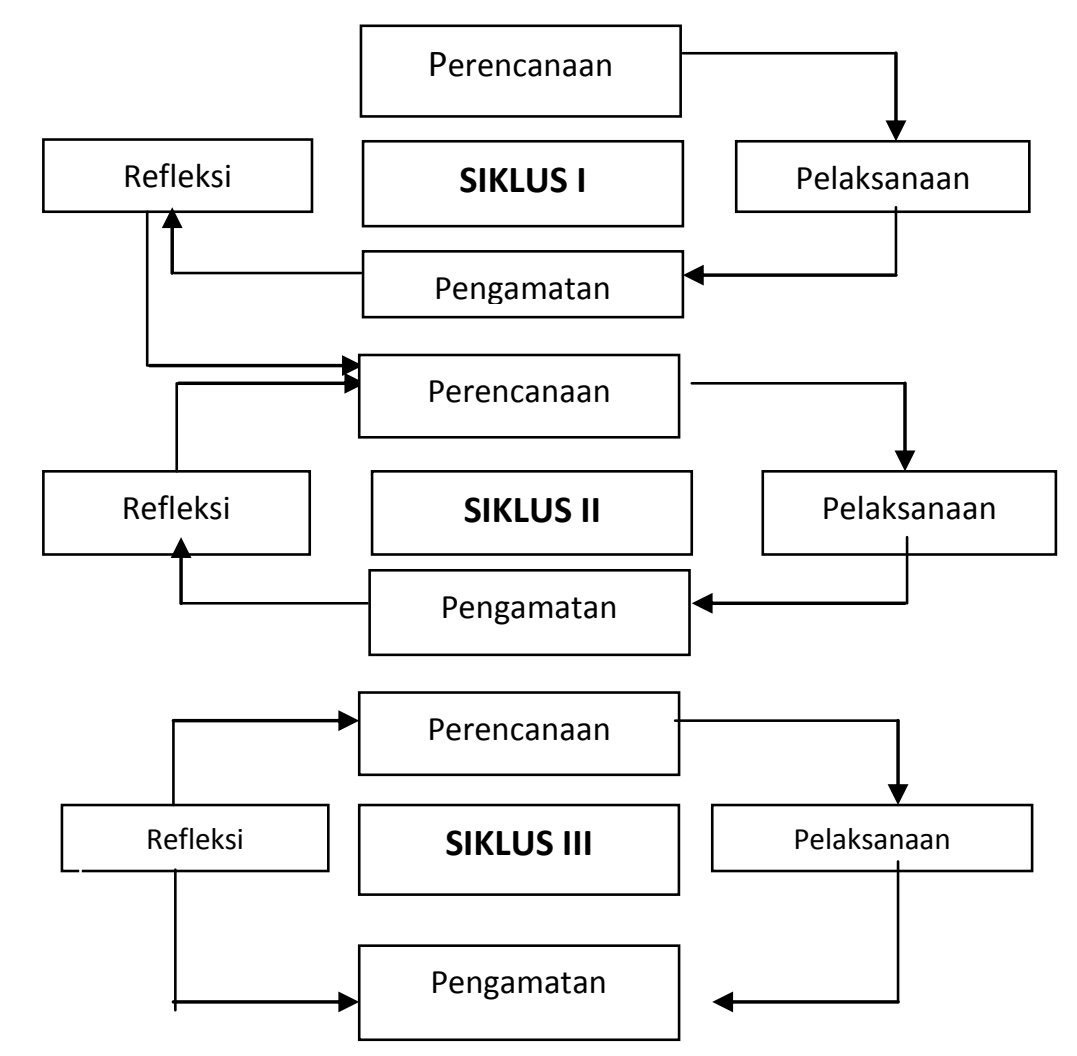

\footnotetext{
${ }^{2}$ Rochiati Wiriaatmadja, Metode Penelitian Tindakan Kelas (Untuk Meningkatkan Kinerja Guru Dan
} Dosen) (Bandung: PT Remaja Rosdakarya, 2007).

69 | At-Tarbiyat : Jurnal Pendidikan Islam, Vol. 03 No. 01 (2020) : 67-85 


\section{Motivasi Belajar}

Kata motivasi berasal dari kata "motif" yang diartikan sebagai daya upaya yang mendorong seseorang untuk melakukan sesuatu. Berawal dari kata "motif" itu, maka motivasi dapat diartikan sebagai daya penggerak yang telah menjadi aktif. Motif menjadi aktif pada saat-saat tertentu, terutama bila kebutuhan untuk mencapai tujuan sangat dirasakan/ mendesak3. Motivasi belajar adalah sesuatu yang menimbulkan semangat atau dorongan belajar4 . Motivasi belajar adalah keadaan dalam pribadi seseorang yang mendorong keinginan individu untuk melakukan kegiatan-kegiatan tertentu guna mencapai suatu tujuan dalam belajar ${ }^{5}$.

Definisi belajar menurut para ahli, diantaranya adalah sebagai berikut :

a. Skinner (dalam Barlow, 1985) seperti yang dikutip Pupuh Fathurrohman dan M. Sobry Sutikno, mengartikan belajar sebagai suatu proses adaptasi atau penyesuaian tingkah laku yang berlangsung secara progresif ${ }^{6}$.

b. Gagne yang dikutip Dimyati dan Mudjiono, belajar merupakan kegiatan yang kompleks. Setelah belajar, orang memiliki ketrampilan, pengetahuan, sikap dan nilai ${ }^{7}$.

c. Belajar adalah suatu aktivitas mental/ psikis yang berlangsung dalam interaksi aktif dengan lingkungan, yang menghasilkan perubahanperubahan dalam pengetahuan-pemahaman, ketrampilan dan nilai sikap (Winkel, 1989: 36).

d. Learning is any relatively permanent change in behavior that is the result of past experienc. ${ }^{8}$ (Belajar adalah perubahan tingkah laku yang relatif tetap yang diakibatkan pengalaman masa lalu).

e. Sedangkan pengertian belajar menurut Sholeh Abdul Aziz dan Abdul Aziz Abdul Majid yang disampaikan oleh muslimah adalah sebagai berikut:

\footnotetext{
${ }^{3}$ A.M. Sardiman, Interaksi Dan Motivasi Belajar Mengajar (Bandung: Rajawali Pers, 2007).

${ }^{4}$ Amna Emda, "Kedudukan Motivasi Belajar Siswa Dalam Pembelajaran," Lantanida Journal 5, no. 2 (2018): 172, doi:10.22373/lj.v5i2.2838.

${ }^{5}$ Ema Dauyah et al., "Jurnal Serambi Ilmu, Volume 19, Nomor 2, Edisi September 2018," Serambi Ilmu 19, no. 2 (2018): 274-90.

${ }^{6}$ Pupuh Fathurrohman and M Sobry Sutikno, "Strategi Belajar Mengajar Melalui Penanaman Konsep Umum \& Konsep Islami,” 2019.

${ }^{7}$ Mudjiono Dimyati, “Belajar \& Pembelajaran,” Jakarta: Rineka Cipta, 2013.

${ }^{8}$ David L Morgan and Robin K Morgan, Single-Case Research Methods for the Behavioral and Health Sciences (Sage publications, 2008).
}

70 | At-Tarbiyat : Jurnal Pendidikan Islam, Vol. 03 No. 01 (2020) : 67-85 


\section{أن التعلم هو تغيير فى ذهن المتعلم بطر أ على خبرة سابقة فيحدث فيها تغيير ا}

جديدا

Belajar adalah proses perubahan dalam pemikiran siswa yang dihasilkan atas pengalaman terdahulu, kemudian terjadi perubahan baru'.

Dari beberapa definisi tersebut, dapat disimpulkan bahwa belajar adalah perubahan yang terjadi di dalam diri seseorang setelah melakukan aktifitas tertentu melalui interaksi dengan lingkungannya.

Jadi, yang dimaksud dengan motivasi belajar adalah keseluruhan daya penggerak di dalam diri siswa yang menimbulkan kegiatan belajar, yang menjamin kelangsungan dari kegiatan belajar dan memberi arah pada kegiatan belajar, sehingga tujuan yang dikehendaki oleh subjek belajar dapat tercapai ${ }^{10}$.

Motivasi belajar merupakan sebuah nilai dan hasrat untuk belajar. Ini berarti bahwa siswa tidak hanya diharapkan belajar namun juga menghargai dan menikmati belajar dengan senang hati. Oleh karena itu, guru perlu memotivasi dan membangkitkan para siswa untuk belajar sehingga tujuan pembelajaran dapat dicapai.

Berdasarkan pengertian di atas, motivasi mengandung tiga elemen penting yaitu: motivasi belajar mengawali adanya perubahan terjadinya energi pada diri setiap individu; motivasi ditandai dengan munculnya rasa atau feeling seseorang; motivasi akan dirangsang karena ada tujuan. Motivasi merupakan sesuatu yang kompleks, akan menyebabkan terjadinya suatu perubahan energi yang ada pada diri seseorang, sehingga berhubungan dengan persoalan kejiwaan, perasaan, emosi dan tujuan.

\section{Aktivitas belajar}

Keaktifan siswa selama proses belajar mengajar merupakan salah satu indikator adanya keinginan atau motivasi siswa untuk belajar. Siswa dikatakan memiliki keaktifan apabila ditemukan ciri-ciri perilaku seperti: sering bertanya

\footnotetext{
${ }^{9}$ Muslimah Muslimah, "PENDIDIKAN DAN METODE PEMBELAJARAN MENURUT SHOLEH ABDUL AZIZ DAN ABDUL AZIZ ABDUL MAJID," At-Ta'lim : Kajian Pendidikan Agama Islam 2, no. 1 (2020): 1-15, http://ejournal.annadwahkualatungkal.ac.id/index.php/Attalim/article/view/130.

${ }^{10}$ Sardiman, Interaksi Dan Motivasi Belajar Mengajar.
}

71 | At-Tarbiyat : Jurnal Pendidikan Islam, Vol. 03 No. 01 (2020) : 67-85 
kepada guru atau siswa lain, mau mengerjakan tugas yang diberikan guru, mampu menjawab pertanyaan, senang diberi tugas belajar, dan lain sebagainya.

Aktivitas belajar menurut Syaiful Bahri Djamara sebagai berikut ${ }^{11}$ :

a. Mendengarkan

Mendengarkan adalah salah satu aktivitas belajar. Setiap orang yang belajar di sekolah pasti ada aktivitas mendengarkan. Ketika seorang guru menggunakan metode ceramah, maka setiap siswa diharuskan mendengarkan apa yang guru sampaikan. Menjadi pendengar yang baik dituntut dari mereka.

b. Memandang adalah mengarahkan penglihatan ke suatu objek. Aktivitas memandang berhubungan erat dengan mata. Karena dalam memandang itu matalah yang memegang peranan penting. Tanpa mata tidak mungkin terjadi aktivitas memandang dapat dilakukan.

c. Meraba, Membau, dan Mencicipi/Mengecap

Aktivitas meraba, membau, dan mengecap adalah indra manusia yang dapat dijadikan sebagai alat untuk kepentingan belajar. Artinya aktivitas meraba, membau dan mengecap dapat memberikan kesempatan bagi seseorang untuk belajar. Tentu saja aktivitasnya harus disadari oleh suatu tujuan.

d. Menulis atau Mencatat merupakan kegiatan yang tidak terpisahkan dari aktivitas belajar. Dalam pendidikan tradisional kegiatan mencatat merupakan aktivitas yang sering dilakukan. Walaupun pada waktu tertentu seseorang harus mendengarkan isi ceramah, namun dia tidak bisa mengabaikan masalah mencatat hal-hal yang dianggap penting.

e. Membaca

Aktivitas membaca adalah aktivitas yang paling banyak dilakukan selama belajar di sekolah atau di perguruan tinggi. Membaca disini tidak mesti membaca buku belaka, tetapi juga membaca majalah, koran, tabloid, jurnal-jurnal hasil penelitian, catatan hasil belajar atau kuliah dan hal-hal lainnya yang berhubungan dengan kebutuhan studi.

f. Membaca Ikhtisar atau Ringkasan dan Menggarisbawahi

Ikhtisar atau ringkasan dapat membantu dalam hal mengingat atau mencari kembali materi dalam buku untuk masa-masa yang akan

\footnotetext{
${ }^{11}$ Syaiful Bahri Djamarah and Aswan Zain, "Strategi Belajar Mengajar," Jakarta: Rineka Cipta, 2006, 46.
}

72 | At-Tarbiyat : Jurnal Pendidikan Islam, Vol. 03 No. 01 (2020) : 67-85 
datang. Untuk keperluan belajar yang intensif, bagaimanapun juga hanya membuat ikhtisar adalah belum cukup. Sementara membaca, pada hal-hal yang penting perlu diberi garis bawah (underlining). Hal ini sangat membantu dalam usaha menemukan kembali materi itu dikemudian hari, bila diperlukan.

g. Mengamati Tabel, diagram dan bagan

Buku-buku ataupun di lingkungan lain sering dijumpai tabel-tabel, diagram, ataupun bagan-bagan. Materi non-verbal semacam ini sangat membantu bagi seseorang dalam mempelajari materi yang relevan. Demikian pula gambar-gambar, peta-peta, dan lain-lain dapat menjadi bahan ilustratif yang membantu pemahaman seseorang terhadap sesuatu hal.

h. Menyusun Paper atau Kertas Kerja

Menyusun paper tidak bisa sembarangan, tetapi harus metodelogis dan sistematis. Metodelogis artinya menggunakan metode-metode tertentu dalam penggarapannya. Sistematis artinya menggunakan kerangka berpikir yang logis dan kronologis.

i. Mengingat

Mengingat yang didasari atas kebutuhan serta kesadaran untuk mencapai tujuan belajar lebih lanjut termasuk aktivitas belajar. Apalagi jika mengingat itu berhubungan dengan aktivitas-aktivitas belajar yang lainnya.

j. Berpikir

Berpikir adalah termasuk aktivitas belajar. Orang berpikir akan memperoleh penemuan baru, setidak-tidaknya orang menjadi tahu tentang hubungan antara sesuatu.

k. Latihan atau Praktek

Learning by doing adalah konsep belajar yang menghendaki adanya penyatuan usaha mendapatkan kesan-kesan dengan cara berbuat. Belajar sambil berbuat dalam hal ini termasuk latihan. Latihan termasuk cara yang baik untuk memperkuat ingatan.

\section{Prestasi belajar}

Prestasi belajar yang dimaksud adalah suatu hasil yang telah dicapai seorang anak setelah adanya aktivitas belajar yang telah ditetapkan di sekolah 
tertentu dalam waktu yang telah ditentukan pula. Prestasi belajar anak terfokus pada nilai atau angka yang telah dicapai anak dalam proses pembelajaran di sekolah.

Mengenai makna dari prestasi belajar yang merupakan satu pengertian dan terdiri dari rangkaian dua kata yakni prestasi dan belajar. Sebelum menguraikan lebih lanjut tentang prestasi belajar terlebih dahulu akan diuraikan pengertian belajar itu sendiri. Pengertian belajar menurut Clifford T. Morgan mengatakan bahwa learning is any relatively permanent change in behavior which occurs as a result of experience or practice ${ }^{12}$. (Belajar adalah perubahan tingkah laku yang relatif tetap yang terjadi akibat pengalaman atau latihan). Sedangkan prestasi merupakan hasil vang dicapai seseorang ketika mengerjakan tugas atau kegiatan tertentu ${ }^{13}$.

Jadi, prestasi belajar yang dimaksud adalah suatu hasil yang telah dicapai seorang anak setelah adanya aktivitas belajar yang telah ditetapkan di sekolah tertentu dalam waktu yang telah ditentukan pula. Prestasi belajar anak terfokus pada nilai atau angka yang telah dicapai anak dalam proses pembelajaran di sekolah. Kemudian untuk mengukur hasil tersebut diselenggarakan evaluasi belajar yang nilainya dituangkan dalam raport. Nilai tersebut terutama dilihat dari sisi kognitif. karena aspek ini yang sering dinilai oleh guru untuk melihat penguasaan pengetahuan sebagai ukuran pencapaian hasil belajar anak.

\section{Strategi pembelajaran Direct Instruction}

Strategi pembelajaran Direct Instruction merupakan suatu model pembelajaran yang bersifat teacher center yang berguna untuk membantu siswa dalam mempelajari dan menguasai ketrampilan dasar, ketrampilan kompleks serta pengetahuan deklaratif, fokus utama dari pembelajaran model direct instruction ini adalah adanya pelatihan- pelatihan yang dapat diterapkan dari keadaan yang sederhana sampai yang lebih kompleks. Model pembelajaran ini membutuhkan keaktifan, kelihaian, ketrampilan dan kreatifitas guru tanpa menghilangkan peran siswa sebagai subyek didik.

\footnotetext{
${ }^{12}$ Morgan and Morgan, Single-Case Research Methods for the Behavioral and Health Sciences.

${ }^{13}$ Tulus Tu'u, "Peran Disiplin Pada Perilaku Dan Prestasi Siswa," Jakarta: Grasindo 82 (2004).
}

74 | At-Tarbiyat : Jurnal Pendidikan Islam, Vol. 03 No. 01 (2020) : 67-85 
Proses pembelajaran tanpa menghilangkan peran sebagai subyek dapat dicontoh membuat media belajar berupa game edukatif. Hal tersebut akan menjadikan peran siswa sebagai subyek utama dalam belajar ${ }^{14}$. Dalam model ini peran guru lebih menonjol dari pada peran siswa, model pembelajaran ini mempunyai beberapa ciri yaitu:

a. Adanya tujuan pembelajaran dan pengaruh model pada siswa termasuk prosedur penilaian hasil belajar.

b. Sintaks atau pola keseluruhan dan alur kegiatan pembelajaran.

c. Sistem pengelolaan dan lingkungan belajar yang diperlukan agar kegiatan pembelajaran tertentu dapat berlangsung dengan berhasil.

Menurut Triantoyang di kutip oleh Zahriani Direct instruction dilaksanakan melalui lima fase. Fase-fase itu dapat dijelaskan sebagai berikut ${ }^{15}$ :

\begin{tabular}{|c|c|c|}
\hline No & Langkah Pembelajaran & Peran Guru \\
\hline 1. & $\begin{array}{l}\text { Menyampaikan tujuan } \\
\text { dan memotivasi siswa }\end{array}$ & $\begin{array}{l}\text { Menjelaskan tujuan pembelajaran, } \\
\text { informasi latar belakang, } \\
\text { pentingnya materi ini dipelajari } \\
\text { dan mempersiapkan siswa untuk } \\
\text { belajar lewat pelatihan }\end{array}$ \\
\hline 2. & $\begin{array}{l}\text { Mendemonstrasikan } \\
\text { pengetahuan atau } \\
\text { ketrampilan }\end{array}$ & $\begin{array}{l}\text { Menampilkan kegiatan dengan } \\
\text { demontrasi ketrampilan atau } \\
\text { menyajikan matteri setahap demi } \\
\text { setahap } \\
\text { mempertimbangkan strukturnya }\end{array}$ \\
\hline 3. & $\begin{array}{l}\text { Men } \\
\text { pela }\end{array}$ & $\begin{array}{l}\text { Guru membimbing pelatihan } \\
\text { kelompok belajar saat mereka } \\
\text { mengerjakan tugas }\end{array}$ \\
\hline 4. & $\begin{array}{l}\text { Mengontrol } \\
\text { penguasaan siswa dan } \\
\text { memberikan umpan } \\
\text { balik }\end{array}$ & $\begin{array}{l}\text { Mengecek keberhasilan } \\
\text { pelaksanaan tugas latihan apakah } \\
\text { siswa berhasil dengan baik dan } \\
\text { diteruskan dengan kegiatan untuk } \\
\text { memperoleh balikan (tes, } \\
\text { wawancara, pengamatan dan } \\
\text { sebagainya. }\end{array}$ \\
\hline 5. & $\begin{array}{l}\text { Memberikan } \\
\text { kesempatan untuk } \\
\text { pelatihan lanjutan dan } \\
\text { menerapkan hasil } \\
\text { latihan }\end{array}$ & $\begin{array}{l}\text { Memberikan latihan lanjutan yang } \\
\text { fokusnya adalah penerapan pada } \\
\text { situasi yang lebih komplek dalam } \\
\text { kehidupan nyata. }\end{array}$ \\
\hline
\end{tabular}

\footnotetext{
${ }^{14}$ R Hadapiningradja Kusumodestoni et al., "Penerapan Algoritma Backpropagation Pada Game Pengenalan Nahwu Di Mi Darul Falah Jepara," POSITIF : Jurnal Sistem Dan Teknologi Informasi 5, no. 2 (2019): 103, doi:10.31961/positif.v5i2.831.

${ }^{15}$ Zahriani Zahriani, “Kontektualisasi Direct Instruction Dalam Pembelajaran Sains,” Lantanida Journal 2, no. 1 (2014): 95, doi:10.22373/lj.v2i1.667.
} 
Ilustrasi pembelajaran Akidah Akhlak dengan menerapkan strategi Direct Instruction adalah sebagai berikut:

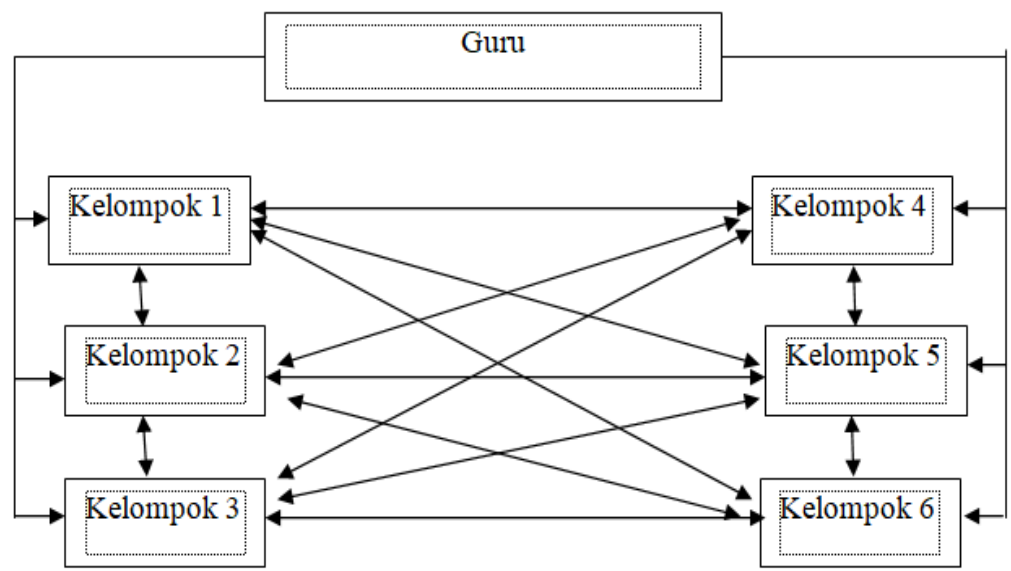

Gambar 1 Ilustrasi pembelajaran dengan strategi Direct Instruction

Di akhir pembelajaran pokok bahasan mengidentifikasi bentuk dan contohcontoh perilaku ikhlas, taat, khauf, dan taubat, siswa diberikan angket motivasi dan pelaksanaan tes akhir siklus.

\section{PEMBAHASAN}

Kegiatanbelajar mengajar mata pelajaran Akidah Akhlak di MTs. YAPIN Kertasemaya Indramayu diwujudkan dalam berbagai bentuk kegiatan, seperti ceramah, diskusi, demonstrasi, tugas mandiri, hafalan, dan diaplikasikan dalam kehidupan di asrama. Adapun pelajaran Akidah Akhlak yang diajarkan dengan menggunakan direct instruction adalah materi-materiyang bersifat hafalan ayatayat al-Qur'an dan hadist-hadist nabi serta pemahaman, penyampaian dan pengamalan terhadap ayat-ayat tersebut.

Sebelum mengaplikasikan Metode direct instruction, seorang guru melakukan perencanaan model pembelajaran langsung (direct instruction) yang akan dipakai dalam kegiatan belajar mengajarkan (KBM)Akidah Akhlak, hal ini dilakukan agar tidak terjadi hal diluar keinginan seperti: ceramah yang bekelebihan, waktu yang telah ditentukan tidak terjadi kekurangan yang mengakibatkan tujuan tidak tercapai, untuk itu dilakukan perencanaan yang matang, seperti : merumuskan tujuan, memilih isi, melakukan analisis tugas, dan merencanakan waktu. 
Hal ini tampak pada data hasil ulangan akhir semester berikut :

\begin{tabular}{|c|l|c|}
\hline No & \multicolumn{1}{|c|}{ Hasil Ulangan Akhir Semester I } & Pencapaian \\
\hline $\mathbf{1}$ & Nilai Tertinggi & 75 \\
\hline $\mathbf{2}$ & Nilai Terendah & 50 \\
\hline $\mathbf{3}$ & Nilai Rata-rata Kelas & 58,67 \\
\hline $\mathbf{4}$ & Jumlah siswa yang belum tuntas belajar & 11 \\
\hline $\mathbf{5}$ & Jumlah siswa yang tuntas belajar & 19 \\
\hline $\mathbf{6}$ & Prosentase ketuntasan belajar secara klasikal & $36,7 \%$ \\
\hline
\end{tabular}

Berdasarkan data pada tabel di atas dapat diketahui bahwa rata-rata nilai hasil ulangan akhir semester 1 (gasal) pada mata pelajaran Akidah Akhlak siswa kelas VIII adalah 58,67 dan ketuntasan belajar yang dicapai sebesar 36,7 \%. Hasil ini menunjukkan bahwa ketuntasan belajar siswa secara klasikal masih rendah karena masih banyak siswa yang belum mencapai kriteria ketuntasan minimal (KKM).

Berdasarkan hasil pengamatan tersebut dapat disimpulkan bahwa dalam sebuah kelas tersebut terdapat beberapa orang siswa yang kurang termotivasi dalam mengikuti pelajaran Akidah Akhlak. Oleh karena itu, dicarilah cara agar dapat meningkatkan motivasi belajar dan aktivitas belajar siswa, sehingga siswa tersebut termotivasi untuk mengikuti proses pembelajaran.

\section{Siklus I}

Setelah Pelaksanaan tes akhir siklus I, menghasilkan data tentang peningkatan prestasi belajar siswa. Hasil evaluasi siswa pada akhir siklus I diperoleh data nilai rata-rata 6,55 dengan persentase ketuntasan belajar Akidah Akhlak sebesar $40 \%$ sebanyak 12 siswa yang tuntas belajar dan 18 siswa yang tidak tuntas belajar. Pada saat tes akhir semua anak masuk. Nilai rata-rata yang dicapai juga belum mancapai standar ketuntasan secara individual 65, atau baru mencapai 59. Prosentase nilai motivasi belajar Akidah Akhlak siswa pada pokok bahasan mengidentifikasi bentuk dan contoh-contoh perilaku ikhlas, taat, khauf, dan taubat adalah sebesar $49,6 \%$. 
Sementara itu, berdasarkan hasil pengamatan terhadap aktivitas belajar siswa dalam pembelajaran sebesar $66,7 \%$ pada pertemuan 1 dan $71,1 \%$ pada pertemuan 2 .

Kegiatan diskusi kelompok pada siklus I ini belum seperti yang diharapkan karena belum semua anggota kelompok ikut aktif dalam menyelesaikan soal LKS dan masih adanya dominasi siswa yang lebih pandai (ketua kelompok). Pada pelaksanaan pembelajaran pertemuan 1 siklus I kemampuan siswa dalam menyelesaikan soal belum begitu baik, ada beberapa kelompok yang masih belum dapat menyelesaikn soal dengan benar. Hasil pekerjaan LKS kelompok belum begitu sempurna.

Pada siklus I ini, perwakilan kelompok yang ditunjuk untuk mempresentasikan hasil diskusinya masih terlihat canggung dan kurang percaya diri, hal ini dikarenakan mereka belum terbiasa untuk menyajikan hasil diskusinya di depan kelas. Pada saat kelompok yang ditunjuk melakukan presentasi tidak banyak kelompok yang mau menanggapi hasil diskusinya, hal ini kemungkinan dikarenakan siswa merasa kurang percaya diri untuk mengemukakan pendapatnya walaupun telah diberi kesempatan. Tapi begitu guru mengkaji ulang jawabannya para siswa mau berkomentar walaupun secara bersama-sama.

\section{Siklus II}

Setelah Pelaksanaan tes akhir siklus II, menghasilkan data tentang peningkatan prestasi belajar siswa. Hasil evaluasi siswa pada akhir siklus II diperoleh data didapat nilai rata-rata 6,82 dengan persentase ketuntasan belajar Akidah Akhlak sebesar sebesar $60 \%$ pada siklus II atau meningkat 20\% dari siklus I Perolehan nilai akhir siklus I prestasi belajar siswa secara klasikal adalah $40 \%$, disusul kemudian pada nilai prestasi belajar pada siklus II sebesar $60 \%$ menunjukkan adanya peningkatan yang cukup signifikan. Peningkatan prestasi belajar secara individual tiap siklus juga mengalami peningkatan, yaitu sebesar 12 siswa mengalami ketuntasan individual atau mendapatkan nilai 65 lebih pada siklus I dan sebanyak 18 siswa mendapatkan nilai 65 lebih pada siklus II. 
Pada tahap akhir pembelajaran, observer dan peneliti memberikan lembar angket untuk mengetahui motivasi belajar siswa dalam mata pelajaran Akidah Akhlak dengan diterapkannya strategi Direct Instruction pada saat siklus II berlangsung. Hasil dari jawaban siswa melalui lembar angket tersebut, memperlihatkan besarnya motivasi belajar siswa, yaitu 77,8\%, atau lebih besar dibanding pada siklus I,

Sementara itu, berdasarkan hasil pengamatan terhadap aktivitas belajar siswa dalam pembelajaran sebesar $75,5 \%$ pada pertemuan 1 dan $80 \%$ pada pertemuan 2.

\section{Siklus III}

Setelah Pelaksanaan tes akhir siklus III, menghasilkan data tentang peningkatan prestasi belajar siswa. Hasil evaluasi siswa pada akhir siklus III diperoleh data didapat nilai rata-rata 7,52 dengan persentase ketuntasan belajar Akidah Akhlak sebesar 80\% pada siklus III atau meningkat 20\% dari siklus II, Perolehan nilai akhir siklus I prestasi belajar siswa secara klasikal adalah $40 \%$, disusul kemudian pada nilai prestasi belajar pada siklus II sebesar 60\% dan pada siklus III sebesar $80 \%$. Hal ini menunjukkan adanya peningkatan yang cukup signifikan. Peningkatan prestasi belajar secara individual tiap siklus juga mengalami peningkatan, yaitu sebesar 12 siswa pada siklus I, 18 siswa pada siklus II dan 24 siswa pada siklus III yang mengalami ketuntasan individual atau mendapatkan nilai 70 lebih

Pada tahap akhir pembelajaran, observer dan peneliti memberikan lembar angket untuk mengetahui motivasi belajar siswa kelas VIII MTs YAPIN Kertasemaya Indramayu pada mata pelajaran Akidah Akhlak dengan diterapkannya strategi Direct Instruction saat siklus III berlangsung. Hasil dari jawaban siswa melalui lembar angket tersebut, memperlihatkan besarnya motivasi belajar siswa, yaitu $81 \%$, atau lebih besar dibanding pada siklus I,

Sementara itu, berdasarkan hasil pengamatan terhadap aktivitas belajar siswa dalam pembelajaran sebesar $84,4 \%$ pada pertemuan 1 dan pada pertemuan 2 sebesar $88,9 \%$. 


\section{Refleksi}

Tes prestasi belajar siswa yang diberikan di setiap akhir siklus digunakan untuk mengetahui tingkat penguasaan siswa terhadap materi pelajaran yang diukur dengan menilai ketuntasan siswa. Ketuntasan siswa terhadap penguasaan materi secara perorangan yang disebut sebagai ketuntasan individual, dan dilihat secara keseluruhan siswa yang mengikuti pembelajaran dari siklus I sampai akhir siklus III disebut sebagai ketuntasan klasikal. Perbandingan penguasaan materi yang diajarkan akan terlihat dalam rerata perolehan nilai, baik sebelum penggunaan model pembelajaran maupun setelah penerapan. Rekapitulasi peningkatan nilai belajar siswa tersebut dapat dilihat dalam tabel 4 berikut:

\begin{tabular}{|c|c|c|c|c|c|}
\hline \multirow[t]{2}{*}{ No } & \multirow[t]{2}{*}{ Hasil Tes } & \multicolumn{4}{|c|}{ Pencapaian } \\
\hline & & Data Awal & $\begin{array}{c}\text { Siklus } \\
\text { I }\end{array}$ & $\begin{array}{c}\text { Siklus } \\
\text { II }\end{array}$ & $\begin{array}{c}\text { Siklus } \\
\text { III }\end{array}$ \\
\hline 1 & Nilai tertinggi & 75 & 7,5 & 7,5 & 8,5 \\
\hline 2 & Nilai terendah & 50 & 60 & 63 & 63 \\
\hline 3 & Nilai rata-rata & 58,67 & 6,55 & 6,82 & 7,52 \\
\hline 4 & $\begin{array}{l}\text { Jumlah Siswa } \\
\text { Tuntas belajar }\end{array}$ & 11 & 12 & 18 & 24 \\
\hline 5 & $\begin{array}{l}\text { Jumlah siswa } \\
\text { tidak tuntas } \\
\text { belajar }\end{array}$ & 19 & 18 & 12 & 6 \\
\hline 6 & $\begin{array}{l}\text { Prosentase } \\
\text { ketuntasan belajar } \\
\text { secara klasikal }\end{array}$ & $36,7 \%$ & $40 \%$ & $60 \%$ & $80 \%$ \\
\hline
\end{tabular}

Sebelum penerapan strategi Direct Instruction dalam pembelajaran Akidah Akhlak, rerata nilai prestasi belajar siswa sebesar 58,67, dengan siswa yang mengalami tuntas belajar sesuai SKM sebanyak 11 siswa $(36,6 \%)$ dan siswa yang belum mengalami tuntas belajar sebanyak 19 orang (63,3\%). Setelah penerapan strategi Direct Instruction dalam pembelajaran Akidah Akhlak, nilai prestasi 80 | At-Tarbiyat : Jurnal Pendidikan Islam, Vol. 03 No. 01 (2020) : 67-85 
belajar siswa meningkat. Hal tersebut dibuktikan pada siklus I rerata nilai prestasi belajar siswa sebesar 6,5, dengan siswa yang mengalami tuntas belajar sebanyak 12 orang $(40 \%)$ dan 18 siswa (60\%) belum tuntas belajar. Sedangkan pada siklus II, rerata nilai prestasi belajar siswa sebesar 6,82, dengan siswa yang mengalami tuntas belajar sebanyak 18 orang (60\%) dan 12 siswa (40\%) belum tuntas belajar. Dan pada siklus III, rerata nilai prestasi belajar siswa sebesar 7,52, dengan siswa yang mengalami tuntas belajar sebanyak 24 orang (80\%) dan 6 siswa $(20 \%)$ belum tuntas belajar. Diagram peningkatan prestasi belajar siswa, dapat dilihat dalam gambar 4.8 berikut:

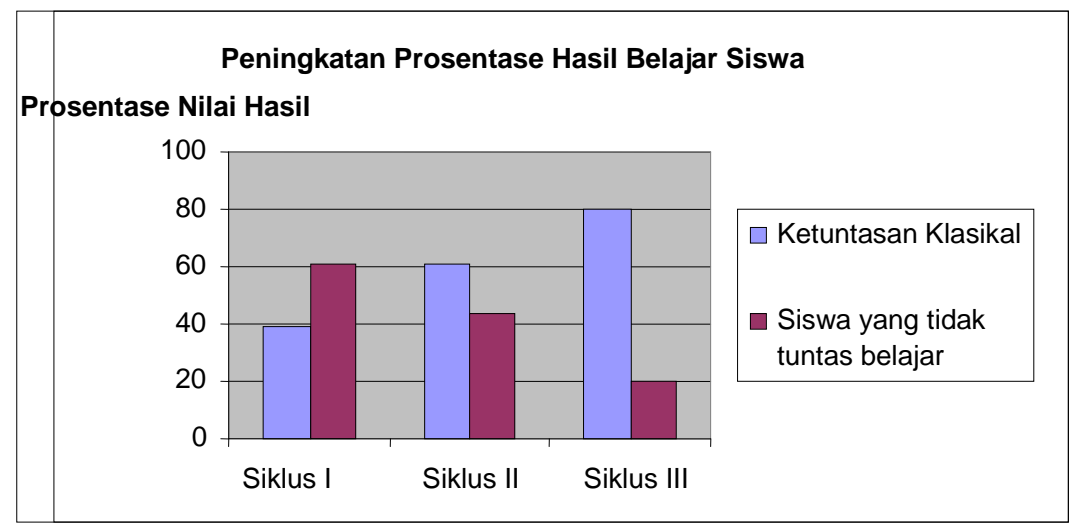

Gambar 2 Peningkatan Prestasi Belajar Siswa Pada Mata Pelajaran Akidah Akhlak

Diagram dalam gambar 4.8 tersebut, memperlihatkan tingkat perbandingan antara siswa yang telah tuntas belajarnya dan tidak tuntas belajarnya mulai dari data awal, siklus I dan siklus II. Peningkatan ketuntasan klasikal tersebut menunjukkan peningkatan yang sangat berarti, hal ini menunjukkan bahwa pembelajaran Akidah Akhlak pada siklus I dan siklus II membawa dampak yang signifikan terhadap prestasi belajar Akidah Akhlak siswa. Dengan demikian, pembelajaran yang berorientasi pada strategi Direct Instruction pada pokok bahasan mengidentifikasi bentuk dan contoh-contoh perilaku ikhlas, taat, khauf, dan tubat dapat menuntaskan belajar siswa atau mampu meningkatkan prestasi belajar siswa.

Berdasarkan hasil produk berupa prestasi belajar dan hasil proses berupa motivasi dan aktivitas belajar, diperoleh gambaran bahwa kompetensi dasar yang dikembangkan oleh peneliti dan mitra telah tuntas dikuasai oleh siswa, dan 
siswa tuntas belajarnya, baik secara individual maupun secara klasikal. Ini berarti bahwa, model pembelajaran dengan menerapkan strategi Direct Instruction pada mata palajaran Akidah Akhlak dengan mengambil pokok bahasan mengidentifikasi bentuk dan contoh-contoh perilaku ikhlas, taat, khauf, dan tubat yang dekembangkan peneliti, mempunyai kualitas proses (motivasi belajar dan aktivitas belajar) dan kualitas hasil/prestasi belajar yang baik.

Hasil tersebut senada dengan yang dikemukakan Gagne dan Leslie Briggs (1988) bahwa pengajaran langsung atau Direct Instruction yang dirancang secara sistematik akan berpengaruh besar terhadap perkembangan individu.

Hasil penelitian ini juga diperkuat dengan: 1) pendapat Borg (1996) dalam Arikunto, dkk. yang menyatakan secara eksplisit bahwa tujuan utama penelitian tindakan kelas ialah pengembangan keterampilan proses yang dihadapi guru di kelasnya16. 2) Dasar utama bagi dilaksanakan “action Research" adalah untuk perbaikan pembelajaran; dan 3) Rapoport yang menyebutkan bahwa penelitian tindakan merupakan pemecahan persoalan-persoalan realistis yang dihadapi dalam pembelajaran sehari-hari17.

Disamping itu, meningkatnya kualitas pendidikan yang salah satunya diperoleh melalui optimalisasi prestasi belajar siswa, berarti guru telah berpartisipasi dalam meningkatkan kualitas sumber daya manusia Indonesia melalui strategi Direct Instruction yang diterapkan dalam pembelajaran Akidah Akhlak kelas VIII MTs YAPIN Kertasemaya Indramayu.

Dari uraian dan pembahasan di atas, maka siklus/tahap dalam penelitian ini merupakan penelitian yang bersifat reflektif, artinya melalui tindakan tertentu untuk memperbaiki dan meningkatkan praktek pembelajaran di kelas secara lebih profesional. Penelitian tindakan kelas ini juga dapat menjembatani kesenjangan antara teori dan praktik pendidikan. Hal ini terjadi karena kegiatan tersebut dilaksanakan sendiri, di kelas sendiri, dengan melibatkan siswanya sendiri melalui tindakan yang direncanakan, dilaksanakan dan dievaluasi.

\footnotetext{
${ }^{16}$ Arikunto Suharsimi and Supardi Suhardjono, "Penelitian Tindakan Kelas (Edisi Revisi)" (PT Bumi Askara, Jakarta, 2017).

${ }^{17}$ Robert N Rapoport, "Three Dilemmas in Action Research: With Special Reference to the Tavistock Experience," Human Relations 23, no. 6 (1970): 499-513, doi:10.1177/001872677002300601.
}

82 | At-Tarbiyat : Jurnal Pendidikan Islam, Vol. 03 No. 01 (2020) : 67-85 
Sehingga diperoleh umpan balik yang sistematis mengenai apa yang selama ini dilakukan dalam kegiatan belajar mengajar.

\section{Rekomendasi}

Berdasarkan hasil penelitian dan pembahasan di atas, penelitian ini memiliki beberapa implikasi, diantaranya:

1. Efektifitas, artinya guru dapat memanfaat waktu yang ada secara maksimal karena materi dan model atau strategi dalam penyampaiannya terstruktur dengan baik.

2. Self-evaluatif, yaitu modifikasi secara kontinyu dievaluasi dalam situasi yang ada, yang tujuan akhirnya untuk meningkatkan praktik pembelajaran.

3. Guru dapat membuat tujuan pembelajaran yang mendeskripsikan tingkah laku apa yang siswa mereka ingin pelajari secara tepat, menyediakan pengalaman-pengalaman belajar seperti praktik, di mana belajarnya siswa dapat dimonitor dan diberikan umpan balik dan memberikan perhatian tertentu pada bagaimana tingkah laku-tingkah laku di kelas lalu kemudian diberikan penghargaan.

4. Menumbuhkembangkan budaya meneliti bagi tenaga kependidikan agar lebih proaktif dalam mencari solusi alternatif untuk selalu meningkatkan prestasi belajar siswa. 


\section{DAFTAR PUSTAKA}

Dauyah, Ema, Ema Dauyah, Universitas Abulyatama, and Aceh Besar. "Jurnal Serambi Ilmu, Volume 19, Nomor 2, Edisi September 2018." Serambi Ilmu 19, no. 2 (2018): 274-90.

Dimyati, Mudjiono. “Belajar \& Pembelajaran.” Jakarta: Rineka Cipta, 2013.

Djamarah, Syaiful Bahri, and Aswan Zain. "Strategi Belajar Mengajar." Jakarta: Rineka Cipta, 2006, 46.

Emda, Amna. "Kedudukan Motivasi Belajar Siswa Dalam Pembelajaran." Lantanida Journal 5, no. 2 (2018): 172. doi:10.22373/lj.v5i2.2838.

Fathurrohman, Pupuh, and M Sobry Sutikno. "Strategi Belajar Mengajar Melalui Penanaman Konsep Umum \& Konsep Islami," 2019.

Kusumodestoni, R Hadapiningradja, Adi Sucipto, Sela Nur Ismiati, and M Novailul Abid. "Penerapan Algoritma Backpropagation Pada Game Pengenalan Nahwu Di Mi Darul Falah Jepara." POSITIF Jurnal Sistem Dan Teknologi Informasi 5, no. 2 (2019): 103. doi:10.31961/positif.v5i2.831.

Morgan, David L, and Robin K Morgan. Single-Case Research Methods for the Behavioral and Health Sciences. Sage publications, 2008.

Muslimah, Muslimah. "PENDIDIKAN DAN METODE PEMBELAJARAN MENURUT SHOLEH ABDUL AZIZ DAN ABDUL AZIZ ABDUL MAJID." At-Ta'lim : Kajian Pendidikan Agama Islam 2, no. 1 (2020): 1-15. http:/ / ejournal.annadwahkualatungkal.ac.id/index.php/Attalim/article/vi ew/130.

Rapoport, Robert N. “Three Dilemmas in Action Research: With Special Reference to the Tavistock Experience." Human Relations 23, no. 6 (1970): 499-513. doi:10.1177/001872677002300601.

Sardiman, A.M. Interaksi Dan Motivasi Belajar Mengajar. Bandung: Rajawali Pers, 2007.

Suharsimi, Arikunto, and Supardi Suhardjono. "Penelitian Tindakan Kelas (Edisi Revisi)." PT Bumi Askara, Jakarta, 2017.

Tu'u, Tulus. "Peran Disiplin Pada Perilaku Dan Prestasi Siswa." Jakarta: Grasindo 82 (2004).

Wibowo, Adi. "STUDY KOMPARASI PENYELENGGARAAN PENDIDIKAN SMK(Studi Kasus SMK Di Pondok Pesantren Lirboyo Al-Mahrusiyah Dan Di 
SMK PGRI 2 Kediri)." At-Tarbiyat :Jurnal Pendidikan Islam 1, no. 2 (2018): 1-22. doi:10.37758/jat.v1i1.100.

Wiriaatmadja, Rochiati. Metode Penelitian Tindakan Kelas (Untuk Meningkatkan Kinerja Guru Dan Dosen). Bandung: PT Remaja Rosdakarya, 2007.

Zahriani, Zahriani. "Kontektualisasi Direct Instruction Dalam Pembelajaran Sains." Lantanida Journal 2, no. 1 (2014): 95. doi:10.22373/lj.v2i1.667. 